\title{
Hubungan antara Loneliness dan Kecanduan Game Online pada Mahasiswa IAIT Kediri
}

\author{
Galuh Anggraini Perwira Sari, ${ }^{1}$ Uswatun Hasanah ${ }^{2}$ \\ ${ }^{1}$ Institut Agama Islam Tribakti (IAIT) Kediri, ${ }^{2}$ Institut Agama Islam Tribakti (IAIT) Kediri \\ ${ }^{1}$ minions.galuh@gmail.com, ${ }^{2}$ uswatun@iai-tribakti.ac.id
}

\begin{abstract}
Online games are very popular among teenagers and adults, because there are many enthusiasts. If the players are constantly without self-control from teenagers and adults, they will become addicted to online games. Feeling lonely makes teens and adults vent through playing online games. This study aims to determine the relationship between loneliness and online game addiction in students who are not settled in a boarding house (nduduk) at IAIT Kediri. With a sample of 40 students who did not settle in a boarding house (nduduk), data collection was obtained from the results of a list of statements or questionnaires for loneliness and addiction to online games. This type of research is quantitative by using correlational research methods namely product moment correlation analysis. Correlation test results obtained correlation coefficient values of 0.556 Sig: 0.00 which means there is a relationship with the criteria being between the loneliness variable with addiction to online games.
\end{abstract}

Keywords: Addicted to Online Games, Loneliness.

\begin{abstract}
Abstrak
Game online sangat populer di kalangan remaja maupun dewasa, karena banyak peminatnya. Jika para pemain terus-menerus tanpa adanya self control dari remaja maupun dewasa akan menjadikan kecanduan game online. Rasa kesepian membuat remaja maupun orang dewasa melampiaskannya dengan bermain game online. Penelitian ini bertujuan untuk mengetahui hubungan antara loneliness dan kecanduan game online pada mahasiswa yang tidak menetap di pondok (nduduk) di IAIT Kediri . Dengan jumlah sampel 40 mahasiswa yang tidak menetap di pondok (nduduk), pengumpulan data diperoleh dari hasil daftar pernyataan atau kuesioner loneliness dan kecanduan game online. Jenis Penelitian adalah kuantitatif dengan menggunakan metode penelitian korelasional yakni analisis korelasi product moment. Hasil uji korelasi didapatkan nilai koefesien korelasi sebesar $0.556 \quad \mathrm{Sig}$ : 0.00 yang artinya terdapat hubungan dengan kriteria sedang antara variabel loneliness dengan kecanduan game online.
\end{abstract}

Kata kunci: Kecanduan Game Online, Kesepian. 


\section{Pendahuluan}

Perkembangan internet saat ini semakin pesat mencapai 143 juta orang, atau sekitar lebih dari 50\% sepanjang tahun 2017. Besar pertumbuhan internet jauh lebih besar dibandingkan dengan jumlah pertumbuhan di Indonesia yang tidak lebih dari 16.15 per tahun. Internet tidak bisa dipisahkan dari kehidupan sehari-hari pada anak muda zaman sekarang, sebanyak 49,52\% pengguna internet di tanah air adalah mereka yang berusia 19-34 tahun dan pemanfaatan internet sudah sangat jauh, bukan hanya untuk berkomunikasi tetapi juga membeli barang, memesan transportasi, berbisnis, berkarya dan bermain. ${ }^{1}$ Semakin tersedianya alat pendukung seperti komputer, laptop hingga smartphone. memudahkan untuk mengakses internet dengan cepat dan mudah. Dalam penelitian yang dilakukan oleh Misyaroh tentang hubungan loneliness dengan mobile phone addict menunjukan terdapat hubungan positif yang signifikan, tingkat mobile phone addict pada mahasiswa mencapai $81 \%$ dan tingkat loneliness $49 \% .^{2}$

Era globalisasi merupakan bagian dari perkembangan zaman, salah satu yang paling nampak yakni mulai tergantikannya permainan tradisional dengan permainan modern. Pada era sekarang banyak anak-anak maupun remaja yang lebih memilih permainan modern dikarenakan permainan modern jauh lebih menyenangkan. Salah satu permainan era modern saat itu yaitu game online. Game online merupakan permainan yang dioperasikan menggunakan koneksi internet. Karena perkembangannya yang begitu pesat membuat para remaja maupun dewasa tertarik untuk menggunakan game online. Sebagaimana yang disampaikan oleh Kepala Intalasi kesehatan jiwa anak dan remaja Kota Surakarta Aliyah Himawati RSJD Solo yang mengatakan bahwa jumlah pasien kecanduan game meningkat, hampir setiap hari ada satu higga dua pasien, pada tahun ajaran baru kemarin terdapat 35 anak dan remaja dengan kecanduan game online yang menjalani pengobatan, dengan keluhan setiap hari selalu memegang HP, tidak dapat melaksanakan tugasnya, suka membolos, tidak mau sekolah, tidak mau belajar dan mudah emosi. ${ }^{3}$

Remaja merupakan masa yang labil emosionalnya mudah sekali tersulut sehingga mudah sekali mengalami stress. Pengalihan masa labil dan stress pada

\footnotetext{
1 Fatimah Kartini Bohang, "Berapa Jumlah Pengguna Internet di Indonesia?," Kompas.com, accessed February 22, 2019, http://tekno.kompas.com.

2 Dewi Ayu Misyaroh, "Hubungan Antara Loneliness dengan Mobile Pkone Addict pada Mahasiswa Universitas Negeri Malang", (Skripsi, Program Strata satu Universitas Islam Negeri Maulana Malik Ibrahim, Malang 2016), 15.

3 Labib zamani, "Kecanduan Game Onlie Puluhan Pelajar Diobati Di Rumah Sakit Jiwa Solo," Kompascom, October 18, 2019, https://regional.kompas.com/read/2019/10/18/06380081/kecanduangame-online.
} 
permainan game online sangat memungkinkan terjadi, hasil penelitian Pranita dan Mabruri menunjukan hasil terdapat hubungan antara emotion focused coping dengan game online addcition pada remaja, hampir $60 \%$ subjek mengalami game onliene addcition dan emotion fucused coping memiliki nilai yang rendah hampir $51 \%{ }^{4}$ Sedangkan penelitian Andriani menemukan bahwa dimensi komunikasi dari keberfungsian keluarga paling berkorelasi dengan kesepian remaja dan tahap perkembangan kesepian remaja akhir juga menunjukan rasa kesepian yang lebih tinggi dibanding remaja awal maupun tengah. ${ }^{5}$

Pemain yang sudah masuk fase kecanduan bermain sangat sulit untuk berhenti dari permainan tersebut. Ada banyak kerugian signifikan dari kecanduan game online salah satunya yaitu menjadi lalai dalam kehidupan nyatanya, lupa dengan tugastugasnya serta kewajiban-kewajiban yang mereka lakukan karena sudah terlalu sering terlibat dalam permainan tersebut. Hasil penelitian Maulidiyah menunjukkan bahwa gambaran profil kepribadian pada remaja yang kecanduan game online memiliki kepribadian yang dominan yaitu remaja memiliki kecenderungan untuk melakukan rutinitas game online dan terdapat kecenderung menarik diri dari lingkungan sosialnya, memiliki keraguan pengambilan keputusan untuk suatu masalah yang secara nyata dalam sehari-hari, kurang mampu membangun hubungan yang lebih matang dengan lingkungan sosial baik teman sebaya maupun orang dewasa. ${ }^{6}$

Dalam Psychology Today sirkuit otak yang mengaktifkan kesenangan juga turut terangsang saat bermain game termasuk bagaian otak yang memproses kebahagian (nucleus acumbens) dan bagian otak yang memproses emosi (amingda) dan bagian otak yang memproses aktivitas visik (orbitol cortek). ${ }^{7}$ Beberapa factor memungkinan seseorang kecanduan game online salah satu pemicunya adalah ketidakbahagian, kekecewaan disebabkan adanya rasa kesendirian kesepian dan timbul rasa jenuh dan bosan sehingga individu berusaha untuk mencari pelarian dalam kegiatan bermain game untuk mengalihkan rasa kesedirian dan kesepianya dengan bermain game, game dipakai

\footnotetext{
4 Hendriyani Mabruri, "Hubungan Emotion Fucused Coping Dengan Game Online Addcition Pada Remaja," Intuisi Jurnal Ilmiah Psikologi 6, no. 1 (March 2014), http://journal.unnes.ac.id/nju/index.php/INTUIS.

5 Andirani Cendra "Hubungan antara Kesepian dan Keberfunsian Keluarga pada Remaja Indonesia" (Skripsi, Program Strata Satu Universitas Indonesia, De0o 2012)

6 Maulidiyah, "Gambaran Profile Kepribadian Pada Remaja Yang Kecanduan Online," Eprints.Umm.Ac.Id, Mei 2012, http://eprints.umm.ac.id/29967/2/jiptummpp-gdl-ummimas ruf-29947-1pendahul-n.pdf.

Dafid J.1 linden,Ph.d "Video Games Can Active The Brain's Pleasure Circuits : http://www.psychologytoday.com/us.bt.ly , 2016
} 
untuk melepaskan dopamine dalam otak sehingga timbul rasa bahagia, untuk mencari kesenangan kebahagian yang dapat menimbulkan ketagihan rasa penasaran untuk mendapatkan skor yang tinggi sehingga timbul dorongan untuk mengulang permainan lagi dengan harapan merasakan bahagia dapat mengalahkan lawan dan mendapatkan skor yang lebih tinggi lagi sehingga mendapatkan pengakuan di kelompok gamer sebagai gamer yang memiliki popularitas yang tinggi di kalangan gamer lain layaknya jagoan yang membuat gamer semakin puas. Menurut para peneliti dari Hammersmith Hospital London tahun 2005 penyebab utama rasa puas dan kecanduan adalah dopamine, hormone dopamine penyebab rasa puas berproduksi berlipat ganda ketika seseorang berhasil mnyelesaikan tantangan di game online.

Kecanduan game online menurut penelitian Anggita Prisilia ada dua faktor yang mempengaruhi kecanduan game online yaitu faktor keluarga dan sosial. ${ }^{8}$ Dalam penelitian yang dilakukan oleh Emmauel dari 448 gamer dewasa yang berpartisipasi terutama adalah lulusan universitas dewasa muda yang tinggal sendirian di area perkotaan menunjukan tingkat tinggi dari kecanduan internet 44,2\% pada Goldberg Skala internet addiction disorder, $36 \%$ pada skala stress internet, positif $27,5 \%$ masuk dalam kategori ketergantungan dalam DSM IV-TR. ${ }^{9}$

Dalam penelitian yang dilakukan oleh Budiana yang betujuan untuk mengetahui hubungan antara loneliness dengan perilaku cyberlofing pada karyawan bidang administrasi menunjukan hasil penelitian bahwa terdapat hubungan signifikan dengan perilaku cyberlofing pada karyawan. ${ }^{10}$ Kesepian dapat terjadi pada siapapun baik itu pada remaja maupun dewasa. Kesepian adalah hal yang dihindari remaja atau dewasa karena pada hakikatnya manusia tidak dapat hidup sendiri, karena manusia adalah makhluk sosial. Para remaja atau dewasa biasanya mengatasi kesepian dengan bermain game online untuk sekedar menghibur diri atau salah satu cara untuk mengatasi kesepian. Kesepian sebagai salah satu penyebab kecanduan yang sering dialami manusia pada masa mahasiswa berkisar antara 18-25 tahun, di mana pada masa itu merupakan masa dewasa awal. Sebagaimana telah ditekankan oleh Hurlock masa

\footnotetext{
8 Anggita Prisilia, “Kecanduan Game Online," accessed January 7, 2019, http://anggitaprisilia.wordpress.com/2017/01/06/kecanduan-game-online/.

9 Emmanuel Haffen Sophia Achab, "Massively Multiplayer Online Role-Playing Games:Comparing Characteristics of Addictvsnon-Addictonline Recruited Gamers in a French Adultpopulation," Achabet al.BMC Psychiatry 144 (2011): 11.

${ }^{10}$ Firda Ayu Budiana "Hubungan antara Loneliness dengan Perilaku Cyberlofing pada Karyawan " (Skripsi Program Strata Satu Unversitas Sunan Ampel, Surabaya, 2018)
} 
dewasa awal merupakan mata "krisis keterpencilan". Hal ini dikarenakan teman-teman sudah berpencar dengan kesibukannya masing-masing. ${ }^{11}$

Dalam penelitian Hilger, transisi dari sekolah ke universitas dikaitkan dengan perubahan sosial, struktural, dan perilaku. Perubahan ini terkait dengan perasaan kesepian didapatkan hasil secara keseluruhan, 32,4\% merasa cukup kesepian dan 3,2\%, sangat kesepian. Kesepian emosional lebih umum daripada kesepian sosial (parah kesepian: $7,7 \%$ vs 3,2\%). Keduanya positif terkait dengan perasaan depresi dan kecemasan. $^{12}$ Kesepian tidak hanya disebabkan karena kesendirian namun respon ketidakadaan suatu hubungan yang diharapkan, ketika seseorang mengalami kesepian seseorang akan merasakan ketidakpuasan, kehilangan dan distress. Tingkat kesepian seseorang berbeda-beda karena situasi orang yang menyebabkan kesepian itu berbeda.

Berdasarkan uraian di atas, salah satu penyebab seseorang kecanduan game online adalah rasa kesendirian kesepian, ketidakbahagian sehingga muncul rasa bosan yang dialihkan pada kegiatan bermain game online. Jika para pemain terus-menerus tanpa adanya self-control dari remaja maupun dewasa akan menjadikan kecanduan game online. Rasa kesepian membuat remaja maupun orang dewasa melampiaskannya dengan bermain game online, oleh karena itu penulis tertarik untuk meneliti apakah ada hubungan antara loneliness dan kecanduan game online pada mahasiswa.

\section{Metode Penelitian}

Kajian ini menggunakan metode penelitian korelasional yakni studi korelasi mempelajari hubungan dua variabel atau lebih, yakni sejauh mana variasi dalam satu variabel berhubungan dengan variasi dalam variable lain. ${ }^{13}$ Studi korelasional (corelational study) disebut juga studi hubungan (Associational study) yakni meneliti hubungan antara dua hal, dua variabel atau lebih. ${ }^{14}$ Cara kerja: Peneliti datang ke sejumlah pemain game online pada mahasiswa yang tidak mondok (nduduk). Peneliti meminta responden untuk bersedia mengisi data dan kuesioner untuk penelitian (informen consent), mencari 40 responden mahasiswa, responden mengisi formulir

\footnotetext{
${ }^{11}$ E.B Hurlock, Psikologi Perkembangan Suatu Pendekatan Sepanjang Rentang Kehidupan (Jakarta: Erlangga, 1999).

12 Hilger kolb Diehl, "Loneliness at Universities: Determinants of Emotional and Social Loneliness Among Students," International Journal of Environmental Research and Public Health 15, no. 1865 (August 29, 2018), https://doi.org/10.3390/ijerph16245128.

${ }^{13}$ Sudjana, Nana, dan Ibrohim, Penelitian dan Penilaian Pendidikan (Bandung: Sinar Baru Aglesindo, 2007), h. 77

${ }^{14}$ Sukmadinata Nana Syaodih, Metodologi Penelitian Pendidikan dan $R \& D$ (Bandung: Remaja Rosda Karya, 2009), h. 57
} 
biodata, kuesioner loneliness, dan kecanduan game online, melakukan uji statistik dari hasil kuesioner lonelines, dan kecanduan game online. Menganalisis hasil statistik untuk mengetahui adakah hubungan antara loneliness dengan kecanduan game online.

Populasi pada penelitian ini adalah seluruh mahasiswa IAIT Kediri. teknik pengambilan sampel dengan menggunakan simple random sampling, Dikatakan simple (sederhana) karena pengambilann anggota sampel populasi dilakukan secara acak tanpa memerhatikan strata yang ada di dalam populasi itu. ${ }^{15}$ Dalam penelitian ada beberapa ketentuan untuk menjadi subjek. Berikut adalah ciri-ciri pada subyek pada penelitian: mahasiswa berusia 18-25 tahun yang mayoritas pemain game online, mahasiswa yang tidak menetap di pondok (nduduk), bermain game online lebih dari 2 jam.

Teknik pengambilan data yang digunakan pada penelitian ini yaitu berupa skala yang berbentuk angket yang disusun dengan menggunakan skala likert. Skala likert digunakan untuk mengukur sikap, pendapat, persepsi, seseorang atau sekelompok orang tentang fenomena sosial. ${ }^{16}$ Skala likert yang di dalamnya terdapat beberapa butir pertanyaan mendukung pernyataan psikologi yang ingin diungkap (favourable) dan tidak mendukung pernyataan psikologi yang diungkap (unfavorable). Jawaban setiap pernyataan/butir instrumen diberikan pada respon dalam tingkat positif hingga negatif. Sebelum menyusun butir pernyataan, terlebih dahulu dirumuskan kisi-kisi instrumen. Kisi-kisi skala loneliness disusun di University California Los Angeles (UCLA) loneliness scale oleh Russel D. Peplau L.A \& Ferguson M.L. terdapat 3 aspek loneliness yaitu emotional loneliness (kesepian emosi), sosial loneliness (kesepian sosial), dan deppression (depresi). Sedangkan skala kecanduan game online yang disusun oleh Lemmens, Valkenburg dan Peter yaitu game addiction scale. terdapat 7 aspek yakni salience (ciri khas), tolerance (toleransi), mood modification (modifikasi suasana hati), withdrawal (penarikan), relapse (pengulangan), conflict (konflik), dan problem (masalah). Penelitian yang berbentuk pendekatan kuantitatif, maka teknik analisis data dengan menggunakan perhitungan statistik untuk menjawab rumusan masalah dan pengujian hipotesis. Dalam pengujian hipotesis ini menggunakan analisis data Pearson Product Moment, analisis uji korelasi (korelasi product moment).

\footnotetext{
${ }^{15}$ Sugiyono, Metode Penelitian, h. 52

${ }^{16}$ Sugiyono. h. 92.
} 


\section{Loneliness}

Loneliness diartikan sebagai perasaan kehilangan dan ketidakpuasan yang dihasilkan oleh ketidaksesuaian antara jenis hubungan sosial yang seseorang inginkan dan jenis hubungan sosial yang dimiliki. ${ }^{17}$ Menurut Weiss, ada dua jenis kesepian yang berbeda: kekurangan hubungan dekat dan intim yang mengarah ke kesepian emosional dan kurangnya jaringan hubungan sosial yang menyebabkan kesepian sosial. $^{18}$ Loneliness atau kesepian sebagai suatu keadaan emosi kognitif yang tidak bahagia disebabkan atas keingininan untuk menjalin hubungan akrab namun tidak tercapai. Kesepian terjadi karena tidak terpenuhinya kebutuhan untuk berkomunikasi dalam membina hubungan persahabatan yang akrab sampai cinta yang mendalam. Disebutkan bahwa individu yang mengalami kesepian sangat membutuhkan orang lain untuk berkomunikasi dan menjalin suatu hubungan timbal balik yang mendalam dan intim, tetapi tidak mampu mewujudkan keinginan tersebut karena berbagai alasan, seperti sifat yang pemalu, rendah diri, ataupun kehilangan orang yang dipercayai sehingga individu dapat mengkomunikasikan perasaanya. ${ }^{19}$

Ketika Individu mempunyai perasaan ingin mengadakan kontak dengan lingungan tetapi individu rasa malah menjadi kekurangan atau individu tidak punya banyak relasi sosial yang banyak, seperti apa yang diingini individu yakni dapat berkontak sosial dengan banyak orang maka individu tersebut mengalami kesepian (loneliness). ${ }^{20}$ Ciri umum yang terdapat pada orang kesepian yaitu tingginya fokus diri sendiri (self focus), terlalu memfokuskan perhatian diri mereka sendiri dan pengalaman pribadinya, orang yang mengalami kesepian sangat menilai dirinya dan orang lain negatif. $^{21}$ Keadaan psikologis yang timbul karena adanya ketidaksesuain antara apa yang diharapkan individu dengan kenyataan yang individu alami dalam membina hubungan sosial dengan orang lain merupakan bentuk dari kesepian. Kesepian akan disertai oleh berbagai macam emosi seperti depresi, kecemasan, ketidakbahagiaan, ketidakpuasan, menyalahkan diri sendiri. ${ }^{22}$

\footnotetext{
17 Perlman L.A.Paul, "Loneliness: A Source Book Of Current, Theory, Reaseach, and Therapy" (New York, 1982), h.12.

${ }^{18}$ Weiss, R.S.Loneliness : The experience of Emotional and Social isolation, The MIT Press : Cambridge, MA,USA, 1973

${ }^{19}$ T. Lake, "Kesepian (Loneliness)" (jakarta: Arcan, 1986), h.61.

${ }^{20}$ G.W.Watson, "Identification of Whitefiles," in Indentification of Whitefiles (Hemipetra: Aleyrodidae, 2007), h.57.

${ }^{21}$ L.A.Paul, “Loneliness: A Source Book OfCurrent, Theory, Reaseach, and Therapy."

22 J.W.Santrock, Child Develovment 5 th Ed, (Dubuque:Wm.C.Brown,1992) hal.113
} 
Menurut beberapa pengertian di atas dapat disimpulkan bahwa loneliness adalah kesepian yang terjadi ketika apa yang diiginkan tidak sesuai dengan kenyataan kehidupannya, merasa sendiri, merasa kosong, merasa diasingkan padahal sebenarnya orang tersebut tidak dalam keadaan sendiri dan berada dalam lingkungan yang ramai dan tidak sedang diasingkan oleh orang lain, perasaan itulah yang membuat seseoramg merasa kesepian.

\section{Kecanduan Game Online}

Kecanduan atau addiction dalam kamus psikologi diartikan sebagai keadaan bergantung secara fisik pada suatu obat bius. Pada umumnya kecanduan tersebut menambah toleransi terhadap suatu obat bius, ketergantungan fisik dan psikologis dan menambah gejala pengasingan diri dari masyarakat apabila obat tersebut tidak dihentikan. $^{23}$ Kecanduan adalah aktifitas yang dilakukan secara berulang-ulang dan menimbulkan dampak negatif salah satunya game online, kecanduan adalah suatu gangguan yang sifatnya menimbulkan rasa ketagihan yang ditandai dengan perbuatan kompulsif yang dilakukan seseorang secara berulang-ulang untuk mendapatkan kepuasan pada aktifitas tertentu. Istilah kecanduan juga digunakan untuk menyebut ketergantungan pada permasalahan sosial seperti kompulsif makan, adiksi shopping bahkan internet khususnya game online. ${ }^{24}$

Terdapat dua macam kecanduan yaitu: physical addiction yaitu jenis kecanduan yang berhubungan dengan alkohol dan non-psysical addiction yaitu jenis kencanduan yang tidak melibatkan alkohol seperti bermain game online dan memiliki ciri sebagai berikut: perilaku tidak terkontrol, adanya konsekuensi sebagai akibat dari perilaku, ketidakmampuan individu mengubah perilaku, terjadinya perubahan mood secara dratis, kegiatan sosial rutinitas kerja dan rekreasi terabaikan karena perilaku kecanduan, menggunakan perilaku sebagai coping, terjadinya perilaku destruktif. ${ }^{25}$

Sedangkan game online adalah sebuah mekanisme permainan berbasis elektronik visual yang menggunakan jaringan komunikasi online atau internet untuk menghubungkan para pemain game di mana terjadi interaksi satu orang dengan yang lainnya untuk mencapai tujuan misi dan meraih nilai tertinggi dalam dunia virtual. Kecanduan game online merupakan salah satu bentuk kencaduan yang disebabkan oleh

\footnotetext{
${ }^{23}$ Kartono Kartini, “Kamus Lengkap Psikologi” (Bajarmasin: Rajawali Press, 2009).

${ }^{24}$ Soejipto, "Bimbingan Konseling Di Sekolah" (Bandung: Pt.Remaja Rosdakarya, 2007), h.4.

${ }^{25}$ C.C.Diclemente, "Addiction and Change" (New York: Guilford Publication, 2003).h.204
} 
teknologi internet baru yang lebih dikenal dengan internet addictive disorder. ${ }^{26}$ Kecanduan game online akibat dari tingginya intensitas atau waktu yang digunakan untuk bermain lebih dari 2-6 jam, seseorang yang sudah mengalami kecanduan cenderung lebih memilih untuk bermain game dari pada mengerjakan pekerjaan lain dan kesulitan untuk melepas permainan tersebut.

Kriteria kecanduan game online meliputi: saliance, apabila bermain game menjadi aktivitas yang sangat penting dalam hidup seseorang dan mendominasi pemikiran, perasaan dan tingkah lakunya, tolerance yaitu meningkatnya waktu bermain, mood modification hal ini mengacu pada pengalaman subjektif melalui bermain game mereka mengalami perasaan yang mengairahkan atau merasakan ketenangan. Wihtdrawal adalah perasaan tidak nyaman atau efek fisik yang timbul ketika kegiatan bermain game dikuramgi atau dihentikan misalnya murung dan mudah marah, conflict interpersonal antara pemain dan orang disekitar mereka, konflik intrapsikis dengan pekerjan karena banyak menyita waktu untuk bermain game online, perasaan subjektif kehilangan control. ${ }^{27}$

\section{Hasil Penelitian}

Sebelum pengujian hipotesis terlebih dahulu dilakukan pengujian data melalui uji validitas dan reabilitas data. Uji validitas untuk memenuhi syarat-syarat alat ukur yang baik, sehingga menghasilkan data yang sesuai dengan apa yang diukur. Pengambilan keputusan untuk validitas data:

- Apabila $\mathrm{r}$ hitung > $\mathrm{r}$ tabel, maka dapat dinyatakan butir pertanyaan Valid

- Apabila $r$ hitung < $r$ tabel, maka dapat dinyatakan butir pertanyaan Tidak Valid. ${ }^{28}$

Dan untuk menentukan $r$ tabel:

Dengan melihat pada tabel distribusi $\mathrm{r}$ tabel berdasarkan DF sebesar N-2 $=40-2$ $=38$ dengan signifikansi 0,05 maka didapat nilai $\mathrm{r}$ tabel sebesar 0,312. Uji validitas pada kuesioner penelitian variabel $(\mathrm{X})$ loneliness yang terdiri dari 20 item dan pembagian kuesioner terhadap mahasiswa yang tidak menetap dipondok ( $n d u d u k$ ) IAIT Kediri sebanyak 40 mahasiswa. Berdasarkan olah data pada tahap 2 yang dibantu oleh aplikasi SPSS versi 23.0 dapat disimpulkan bahwa 12 item pertanyaan pada variabel (X)

26 K.Young, "Cyber -Disorders: 'The Mental Healt Concren For the New Millenium," Journal CyberPsycholoy \& Beahvior (Online) 3, no. 5 (March 21, 2013): h.475.

27 MD.Griffths, "Video Game Addiction: Does It Exist, (Handbook of Computer Studies)" (Boston: MIT Press, 2005), h,359.

28 Ali Anwar, Statistika untuk Penelitian Pendidikan dan Aplikasinya dengan SPSS dan Excel (Kediri: IAIT Press, 2009).h.13. 
loneliness pada penelitian ini dinyatakan valid. Karena nilai $\mathrm{r}$ hitung seluruh item pertanyaan lebih besar dari $\mathrm{r}$ tabel 0,312 . Selanjutnya uji validitas kuesioner penelitian variable (Y) kecanduan game online yang terdiri dari 42 item. Pembagian kuesioner terhadap mahasiswa yang tidak menetap di pondok (nduduk) IAIT Kediri sebanyak 40 mahasiswa. Berdasarkan olah data pada tahap 2 yang dibantu oleh aplikasi SPSS versi 23.0 dapat disimpulkan bahwa 26 item pertanyaan pada variabel Kecanduan Game online pada penelitian ini dinyatakan valid. Karena nilai $r$ hitung seluruh item pertanyaan lebih besar dari $\mathrm{r}$ tabel 0,312 .

Setelah uji validitas tahap selanjutnya yaitu uji reabilitas lonelines tahap 2 Berdasarkan hasil pengolahan data di atas, nilai Cronbach's Alpha sebesar 0,821 lebih dari 0,600 maka dapat disimpulkan bahwa kuesioner pada variabel(X) loneliness dinyatakan reliabel. Hasil uji realibilitas variabel (Y) kecanduan game online didapatkan hasil sebesar 0,901 lebih dari 0,600 maka dapat disimpulkan bahwa kuesioner pada variabel (Y) kecanduan game online dinyatakan reliabel. Variabel (X dan Y) dinyatakan reliabel yaitu terdapat pemahaman responden terhadap pertanyaanpertanyaan dalam kuesioner yang diajukan.

Tahap selanjutnya setelah uji validitas dan reliabilitas yaitu uji normalitas yang digunakan untuk mengetahui apakah data terdistribusi dengan normal atau tidak, analisis parametris seperti regresi linier mensyaratkan bahwa data harus terdistribusi dengan normal. Uji yang digunakan dalam penelitian ini menggunakan metode Uji Normalitas Kolmogorov-Smirnov dalam program aplikasi software SPSS Versi 23.0. Dasar pengambilan keputusan dalam uji normalitas yakni: jika nilai signifikansi lebih besar dari 0,05 maka data tersebut berdistribusi normal. Sebaliknya, jika nilai signifikasi lebih kecil dari 0,05 maka data tersebut tidak berdistribusi normal. Berdasarkan output di atas, diketahui bahwa nilai Asymp. Sig. (2-tailed) variabel (X) Loneliness sebesar 0,125 lebih besar dari 0,05 sehingga dapat disimpulkan bahwa pada data variabel tersebut berdistribusi normal. Sajian tabel di bawah ini merupakan hasil dari uji normalitas data.

Tabel 1: Uji Normalitas Tahap 2 Kecanduan Game Online Metode Kolmogorov Smirnov One-Sample Kolmogorov-Smirnov Test

\begin{tabular}{|l|l|r|}
\hline \multicolumn{2}{|l|}{} & \multicolumn{1}{|c|}{$\begin{array}{c}\text { Kecanduan Game } \\
\text { Online }\end{array}$} \\
\hline $\mathrm{N}$ & Mean & 40 \\
\cline { 2 - 3 } Normal Parameters & Std, Deviation & 88,2250 \\
\hline Most Extreme Differences & Absolute & 14,15570 \\
\hline
\end{tabular}




\begin{tabular}{|l|l|r|}
\hline & Positive & 0,136 \\
\cline { 2 - 3 } & Negative & $-0,125$ \\
\hline Test Statistic & 0,136 \\
\hline Asymp. Sig. (2-tailed) & $0,060^{c}$ \\
\hline
\end{tabular}

Berdasarkan output di atas, diketahui bahwa nilai Asymp. Sig. (2-tailed) variabel kecanduan game online sebesar 0,060 lebih besar dari 0,05 sehingga dapat disimpulkan bahwa pada data variabel tersebut berdistribusi normal. Variable (X dan Y) dinyatakan normal yaitu data tersebut terdistribusi normal. Tahap selanjutnya yaitu pengujian hipotesis, pengujian hipotesis dilakukan dengan menggunakan teknik analisis korelasi product moment melalui program SPSS versi 23.0. Adapun hipotesis sementara adalah " $\mathrm{Ha}=$ terdapat hubungan antara loneliness dengan kecanduan game online pada mahasiswa yang tidak menetap di pondok (nduduk) IAIT Kediri dan "Ho= tidak terdapat hubungan antara loneliness dengan kecanduan game online pada mahasiswa yang tidak menetap di pondok (nduduk) IAIT Kediri."

Untuk menjawab pernyataan pada hipotesis, dilakukan analisis dengan statistik parametrik menggunakan rumus korelasi product moment karena data ini berdistribusi normal, maka dilakukan analisis korelasi product moment. Berikut tabel hasil perhitungan korelasi product moment.

Tabel 2: Uji Korelasi Product Moment

Correlations

\begin{tabular}{|c|c|c|c|}
\hline & & Loneliness & $\begin{array}{c}\text { Kecanduan Game } \\
\text { Online }\end{array}$ \\
\hline Loneliness & Pearson Correlation & 1 & $0,556^{* *}$ \\
\hline & Sig. (2-tailed) & & 0,000 \\
\hline & $\mathrm{N}$ & 40 & 40 \\
\hline Kecanduan Game Online & Pearson Correlation & 0,556 & 1 \\
\hline & Sig. (2-tailed) & 0,000 & \\
\hline & $\mathrm{N}$ & 40 & 40 \\
\hline
\end{tabular}

Berdasarkan ouput tabel correlations di atas diketahui bahwa $\mathrm{N}$ atau jumlah data penelitian adalah 40, kemudian nilai sig. (2-tailed) loneliness dan kecanduan game online adalah 0,000 lebih kecil dari 0,05, sebagaimana dasar pengambilan keputusan di atas, maka hipotesis nol (H0) ditolak dan dapat disimpulkan bahwa terdapat hubungan yang signifikan antara kecanduan game dengan loneliness. 
Selanjutnya, dari output di atas diketahui correlation coefficient (koefisien korelasi) sebesar 0,556. Nilai koefisien positif artinya apabila nilai pengetahuan di tingkatkan maka nilai loneliness akan ikut meningkat. Kriteria hubungan antara variabel kecanduan game online dengan loneliness menunjukan kriteria sedang.

Hasil dari penelitian ini dibantu dengan menggunakan alat bantu software SPSS 23.0 pada judul "hubungan antara Loneliness dengan kecanduan game online pada mahasiswa yang tidak menetap di pondok (nduduk) IAIT Kediri dan menghasilkan kesimpulan sebagai berikut :

1. Ada korelasi antara loneliness dan kecanduan game online pada mahasiswa yang tidak menetap di pondok (nduduk) IAIT Kediri.

2. Korelasi antara loneliness dan kecanduan game online pada mahasiswa yang tidak menetap di pondok (nduduk) IAIT Kediri adalah kriteria sedang, sebesar 0,556 dengan signifikasi 0,000 .

Berdasarkan hasil analisis data maka dapat disimpulkan bahwa ada hubungan yang positif antara loneliness dan kecanduan game online pada mahasiswa yang tidak menetap di pondok (nduduk) IAIT Kediri. Hal ini dapat dibuktikan berdasarkan hasil perhitungan uji korelasi antara variable $\mathrm{X}$ dan variable $\mathrm{Y}$ diperoleh skor sebesar 0,556, sedangkan untuk $\mathrm{r}$ tabel dengan $\mathrm{N}=40$ pada taraf 5\% diperoleh 0,312. Jelas bahwa $\mathrm{r}_{\mathrm{xy}}>$ r tabel, koefisien korelasi menunjukan 0,556 maka dapat dikatakan hubungan antara variabel $\mathrm{X}$ dan $\mathrm{Y}$ adalah hubungan yang sedang. Dan nilai sig. (2-tailed) loneliness dan kecanduan game online adalah 0,000 lebih kecil dari 0,05, sebagaimana dasar pengambilan keputusan pada bagian sebelumnya, maka hipotesis nol (H0) ditolak dan dapat disimpulkan bahwa terdapat hubungan yang signifikan antara kecanduan game dengan loneliness. Dengan demikian hipotesis yang berbunyi yakni ada hubungan antara loneliness dan kecanduan game online pada mahasiswa yang tidak menetap di pondok (nduduk) IAIT Kediri diterima kebenarannya.

\section{Pembahasan}

Mahasiswa yang sedang mengalami kesepian cenderung untuk melampiaskan rasa kesepiannya dengan mencari kesibukan salah satu di antarannya bermain game online yang rata-rata bermain game online lebih dari 2 jam. Seperti yang dikemukakan oleh Hurlock, kesepian dapat terjadi pada siapapun baik itu pada remaja maupun dewasa. Kesepian adalah hal yang dihindari remaja atau dewasa, karena manusia merupakan makhluk sosial. Kesepian sebagai sering dialami manusia yang berumur 18-25 tahun, di 
mana masa itu masa dewasa awal, yang merupakan mata "krisis keterpencilan". Hal ini disebabkan teman-teman sudah berpencar dengan kesibukannya masing- masing. ${ }^{29}$ Kesepian tidak hanya disebabkan kesendirian namun respon ketidakadaan suatu hubungan yang diharapkan, ketika mahasiswa mengalami kesepian mereka juga akan mengalami ketidakpuasan, kehilangan, juga distress.

Pada penelitian ini kriteria kesepian yang terjadi di kalangan mahasiswa yakni karena teman-teman sudah sibuk dengan kesibukannya masing-masing, tak hanya itu melainkan merasa dirinya sendiri dan terasing, padahal sebenarnya dirinya sedang tidak sendirian dan tidak pada keadaaan yang sepi, kurangnya komunikasi atau pembahasan pembicaraan dengan teman-teman yang membuat mereka merasakan kesepian.

Seperti yang telah diketahui, game online merupakan suatu bentuk permainan yang harus terhubung dengan koneksi internet. Pada penelitian ini mahasiswa yang bermain game online merupakan mahasiswa yang tidak menetap di pondok, mempunyai handphone yang berfasilitas adanya koneksi internet dan game. Kriteria game online dalam penelitian ini terhubung koneksi internet seperti Hago, Mobile Legend, dan PUBG. Yang mahasiswanya bermain game online lebih dari 2 jam perhari.

Berdasarkan teori yang sudah dijelaskan di atas berdasarkan data mengenai adanya hubungan yang cukup antara loneliness dan kecanduan game online, salah satu penyebabnya ialah seseorang yang tidak percaya diri dalam bersosialisasi karena mereka lebih merasa percaya diri ketika bersosialisasi dengan orang lain. Karena di dalam game online individu bisa berinteraksi dengan orang lain. Di saat merasakan kesepian individu yang tidak mempunyai aktifitas rutinan melakukan aktivitas bermain game online, dalam jangka waktu yang lama, dan terus menerus melakukan kegiatan bermain game online, tidak bisa berhentinya seseorang dalam bermain game online dan dalam jangka waktu yang lama bisa disebut dengan kecanduan game online.

\section{Kesimpulan}

Menurut hasil penelitian di atas tingkat kesepian yang meningkat menunjukkan tingginya tingkat kecanduan bermain game online. Begitu juga sebaliknya, apabila tingkat kesepiannya menurun maka akan diikuti rendahnya tingkat kecanduan bermain game online. Tingkat kecanduan bermain game online pada mahasiswa yang tidak menetap di pondok (nduduk) IAIT Kediri bisa dikatakan kriteria sedang, tetapi masih

\footnotetext{
${ }^{29}$ E.B Hurlock, Psikologi Perkembangan Suatu Pendekatan Sepanjang Rentang Kehidupan ., h. 13 
bisa diturunkan lagi tingkat kecanduannya. Dengan cara menambahkan kegiatan atau aktifitas rutinan setiap hari. Bagi mahasiswa yang sudah kecanduan bermain game online cobalah untuk mengurangi porsi bermain game online sedikit demi sedikit walau rasa kesepian yang bisa hadir kapan saja namun bermain harus sesuai dengan porsinya dan jangan berlebihan. Penelitian ini mempunyai keterbatasan, antara lain: Pertama, subjek penelitian terbatas, yakni sebanyak 40 orang, karena mayoritas mahasiswa IAIT Kediri bertempat tinggal di pondok. Kedua, terdapat sedikit hambatan karena saat penelitian berlangsung kegiatan perkuliahan kampus IAIT kediri belum aktif, sehingga peneliti perlu untuk menyusuri mahasiswa yang nduduk, namun hal itu tidak begitu mengganggu jadi penelitian tetap berjalan dengan baik.

\section{Daftar Rujukan}

Anggita Prisilia. “Kecanduan Game Online.” Accessed January 7, 2019. http://anggitaprisilia.wordpress.com/2017/01/06/kecand uan-game-online/.

Anwar, Ali. Statistika Untuk Penelitian Pendidikan Dan Aplikasinya Dengan SPSS Dan Excel. KEdiri: IAIT Press, 2009.

C.C.Diclemente. "Addiction and Change." New York: Guilford Publication, 2003.

Diehl, Hilger kolb. "Loneliness at Universities: Determinants of Emotional and Social Loneliness Among Students." International Journal of Environmental Research and Public Health 15, no. 1865 (August 29, 2018). https://doi.org/10.3390/ijerph16245128.

E.B Hurlock. Psikologi Perkembangan Suatu Pendekatan Sepanjang Rentang Kehidupan. Jakarta: Erlangga, 1999.

Fatimah Kartini Bohang. "Berapa Jumlah Pengguna Internet di Indonesia?" Kompas.com. Accessed February 22, 2019. http://tekno.kompas.com.

G.W.Watson. "Identification of Whitefiles." In Indentification of Whitefiles, h.57. Hemipetra: Aleyrodidae, 2007.

Hendriyani Mabruri. "Hubungan Emotion Fucused Coping Dengan Game Online Addcition Pada Remaja.” Intuisi Jurnal Ilmiah Psikologi 6, no. 1 (March 2014). http://journal.unnes.ac.id/nju/ind ex.php/INTUIS.

Kartini, Kartono. “Kamus Lengkap Psikologi.” Bajarmasin: Rajawali Press, 2009.

K.Young. "Cyber -Disorders: 'The Mental Healt Concren For the New Millenium.", Journal CyberPsycholoy \& Beahvior (Online) 3, no. 5 (March 21, 2013): h.475.

Labib zamani. "Kecanduan Game Onlie Puluhan Pelajar Diobati Di Rumah Sakit Jiwa Solo." Kompascom, October 2019. https://regional.kompas.com/read/2019/10/18/06380081/kecanduan-gameonline.

L.A.Paul, Perlman. "Loneliness: A Source Book Of Current, Theory, Reaseach, and Therapy," h.12. New York, 1982. 
Maulidiyah. "Gambaran Profile Kepribadian Pada Remaja Yang Kecanduan Online." Eprints.Umm.Ac.Id, Mei 2012. http://eprints.umm.ac.id/29967/2/jiptummpp-gdlummimasruf-29947-1-pendahul-n.pdf.

MD.Griffths. "Video Game Addiction: Does It Exist, (Handbook of Computer Studies)," h,359. Boston: MIT Press, 2005.

Soejipto. "Bimbingan Konseling Di Sekolah," h.4. Bandung: Pt.Remaja Rosdakarya, 2007.

Sophia Achab, Emmanuel Haffen. "Massively Multiplayer Online Role-Playing Games:Comparing Characteristics of Addictvsnon-Addictonline Recruited Gamers in a French Adultpopulation." Achabet al.BMC Psychiatry 144 (2011): 11 .

Sudjana, Nana, and Ibrohim. Penelitian Dan Penilaian Pendidikan. Bandung: Sinar Baru Aglesindo, 2007.

Sugiyono. Metode Penelitian Kuantitatif Kualitatif Dan R\&D. Bandung: Alfabeta, 2007.

Sukmadinata Nana Syaodih. Metodologi Penelitian Pendidikan Dan R\&D. Bandung: Remaja Rosda Karya, 2009.

T. Lake. “Kesepian (Loneliness),” h.61. jakarta: Arcan, 1986. 